\title{
Purification Characterization and Inhibition Studies on Phospholipase C From Opisthacanthus Capensis (Black Scorpion) Venom
}

\author{
*Y. Tijani, H. Zanna, A. B. Sadiq, B. Modu, M. A. Gadaka, B. B. Shehu and A. A. Abdurrahman \\ Department of Biochemistry, University of Maiduguri, P.M.B. 1069, Maiduguri, Borno State, Nigeria
}

[ ${ }^{*}$ Corresponding author: E-mail: ytgalangi@gmail.com; 8:08038400606]

\begin{abstract}
Phospholipase C from Opisthacanthus capensis venom was partially purified and characterized. The enzyme was purified 105.2 fold with an overall yield of $13 \%$ using various purification steps involving ammonium sulphate precipitation, protamine sulphate treatment, sephadex G-75 fractionation and DE-52 anion exchange chromatography. The purified enzyme was homogeneous with a molecular weight of 29 $\mathrm{kDa}$. The phospholipase $\mathrm{C}$ has $\mathrm{pH}$ and temperature optima of 7.2 and $60^{\circ} \mathrm{C}$, respectively with activation energy of $25 \mathrm{KJ} / \mathrm{mol}$ and $t_{1 / 2}$ of $1.50 \mathrm{hr}$. Initial velocity studies on 0 . capensis venom phospholipase $\mathrm{C}$ revealed a $\mathrm{K}_{\mathrm{M}}$ of $0.02 \mathrm{mM}$ and $\mathrm{V}_{\max }$ of $0.015 \mu \mathrm{mol} / \mathrm{min}$. Studies on the effect of $\mathrm{pH}$ on $\mathrm{K}_{\mathrm{M}}$ and $\mathrm{V}_{\max }$ gave $\mathrm{PKa}_{1}$ of 6.9 and $\mathrm{PKa}_{2}$ of 7.4 with enthalpy of ionization of $20 \mathrm{KJ} / \mathrm{mol}$ suggesting histidine in the active site. The enzyme was positively modulated by $\mathrm{Mg}^{2+}, \mathrm{Zn}^{2+}$ and $\mathrm{Ca}^{2+}$ and negatively by $\mathrm{Fe}^{2+}$. While $\mathrm{Hg}^{2+}$ produced complete inhibition. Various concentrations of leaf aqueous extract of Momordica charantia also inhibited the activity of $O$. capensis venom phospholipase $C$ in vitro with a competitive pattern. This study revealed the presence of phospholipase $\mathrm{C}$ in $\mathrm{O}$. capensis venom and gave some scientific basis for the use of the plant in the treatment of scorpion envenomation.
\end{abstract}

Keywords: Phospholipase C; Opisthacanthus capensis; Momordica charantia; Venom

\section{INTRODUCTION}

Scorpion venom contains numerous toxins, biogenic amines, enzymes, salt, unidentified substances and water. The venom also contains many protein, peptides and other compounds, several of which are biologically active and found to be particularly useful in physiological and pharmacological research as investigatory tools (Petricevich, 2010]. Venom toxicity varies according to several factors such as genus, species, age, physiology, feeding state and geographical location of the scorpion (Emam et al., 2008). Hence, there is a strong demand to obtain venom from various species of scorpions for research purposes (Emam et al., 2008). Scorpion venom causes haemolysis. Some of the haemolytic activity caused by the venom is due to phospholipase $C$ and other haemolytic enzymes such as phospholipase $A_{2}$. Phospholipase C (phosphatidylcholine phosphohydrolase, EC 3.1.4.3) is found in various toxin secreting organisms such as $P$. aeruginosa (Allan and Michell, 1974). Phospholipase C, a glycolipid and alkaline phosphatase is believed to function cooperatively in liberating inorganic phosphate from phospholipids (Bertognolo et al., 2007). The proposed mechanism involves the action of phospholipase C on glycolipid-solubilized phospholipids to liberate phosphorylcholine which can then be hydrolyzed by alkaline phosphatase to yield free phosphate (Bertognolo et al., 2007).

Phospholipase $\mathrm{C}$ comes in multiple forms and plays a key role in the signal transduction process for many receptors (Urbina et al., 2011). Its main function is to hydrolyze phosphatidylinositol diphosphate into diacylglycerol (DG) and inositol triphosphate (IP3) (Urbina et al., 2011). DG is necessary for further activation of protein kinase C while IP3 leads to the release of intracellular calcium (Urbina et al., 2011). DG and IP3 are the second messengers (Bertognolo et al., 2007). IP3 binds to ligandgated $\mathrm{Ca}^{2+}$ channels on internal membranes leading to an influx of calcium ions into the cytoplasm (Bertognolo et al., 2007). High 
intracellular $\mathrm{Ca}^{2+}$ can increase the risk of mitochondrial damage (Bertognolo et al., 2007). This can cause excitotoxicity, resulting in further activation of endonucleases and protease (calpain) leading to damage to the cell structures such as cytoskeleton, cell membrane and DNA (Bertognolo et al., 2007). Excitotoxicity may be involved in neurodegenerative disease of the central nervous system (CNS) such as multiple sclerosis (Kumar et al., 2009). Evidence suggests that phospholipase $C$ (as alpha toxins) is the main virulent factor for gas gangrene in humans.

The lipase activity assists toxin-producing organism to generate lipid signals in the host eukaryotic cell, and ultimately degrade the host cell membrane (Urbina et al., 2011).

Haemoglobinuria, acute tubular necrosis, interstitial nephritis and haemolytic-uraemic syndrome have been documented in human victims of scorpion envenomation (Kumar et al., 2009).. The haemolytic activity can be related to the venoms effects on disrupting the phospholipid bilayer (Kumar et al., 2009). It is therefore, of interest to screen scorpion venoms for the specific enzymes (such as phospholipase C) believed to be responsible for carrying out this activity and to, evaluate the inhibitory effect of Momordica charantia (Guna, in Hausa language and Tumbul fari in kanuri language).

\section{MATERIALS AND METHODS Chemicals}

All chemicals and reagents used in this study were of analytical grade and were purchased from various sources. Opisthacanthus capensis were collected in Bam Bam village of Balanga local government, Gombe State, Nigeria and was authenticated by Dr. A. M. Kokori of Biological Sciences Department, University of Maiduguri, Maiduguri, Nigeria.

\section{Methods}

\section{Plant Extract Preparation by Maceration}

Exactly $20 \mathrm{~g}$ of the ground sample from the leaf of Momordica charantia were mixed with about $100 \mathrm{ml}$ of distilled water in a conical flask stirred, covered with foil paper, and allowed to stand overnight with occasional shaking. The supernatant formed was then carefully decanted into a conical flask $(100 \mathrm{ml})$. This process was repeated until the supernatant became colorless. The average room temperature during the extraction was 27 Celcius. The fraction obtained was then filtered using a clean filter paper.

\section{Venom Extraction}

Venom was extracted by crushing the scorpion tail (telson) into a $50 \mathrm{mM}$ Tris- $\mathrm{HCl}$ buffer $\mathrm{pH} 7.2$ at $40^{\circ} \mathrm{C}$ in a cleaned centrifuge tube. After centrifugation at $10,000 \times \mathrm{g}$, the supernatant was collected and used as crude enzyme.

\section{Total Protein Estimation and Enzyme Assay} The UV spectrophotometric method was used to estimate total protein content (Stoscheck, 1990). Phospholipase C (PLC) assay was carried out as described by Kurioka and Matsuda, (1976). The assay was carried out at $35^{\circ} \mathrm{C}$ in a cuvette with a $10 \mathrm{~mm}$ optical path length. This method was based on the principle that phospholipase $C$ hydrolyses $\quad p$-nitrophenylphosphorylcholine (pNPPC) to phosphorylcholine and p-nitrophenol which is, monitored spectrophotometrically at 410 $\mathrm{nm}$. The buffer used was Tris $\mathrm{HCl} \mathrm{pH} 7.2$ in $60 \%$ sorbitol. Exactly $200 \mu \mathrm{L}$ substrate, $200 \mu \mathrm{L}$ crude (from each centrifuged fraction) and $100 \mu \mathrm{L} 60 \%$ sorbitol in Tris-Hcl buffer pH 7.2 was used for the assay.

\section{Phospholipase C Purification and Molecular Weight Estimation}

The Purification of Phospholipase C was conducted as follows: precipitation with Ammonium Sulphate The crude PLC (3 $\mathrm{ml}$ for each grade) was precipitated using gradient solutions of ammonium sulphate saturation $(20 \%$, $25 \%, 30 \%, 35 \%, 40 \%, 45 \%, 50 \%, 55 \%, 60 \%$, $65 \%, 70 \%, 75 \%, 80 \%$ and $90 \%)$. Each fraction was centrifuged at $10,000 \times \mathrm{g}$ for 20 min after standing overnight at $4^{\circ} \mathrm{C}$. Phospholipase $\mathrm{C}$ activity and total protein were estimated in the precipitate as well as the supernatant for each fraction. The ammonium sulphate fraction that gave the highest specific activity was treated with 
$3 \mathrm{~mL} 2 \%$ protamine sulphate ( $\mathrm{pH}$ adjusted to 7.2 ) and was allowed to stand for $10 \mathrm{~min}$ at $37^{\circ} \mathrm{C}$ then centrifuged at $10,000 \times \mathrm{g}$ for 15 minutes. The precipitate was then discarded and the supernatant was subjected to gel purification using sephadex G-75. The gel was preequilibrated with $0.05 \mathrm{M}$ Tris- $\mathrm{HCl}$ buffer $\mathrm{pH} 7.2$ for 6 hours. The column $(2 \times 50 \mathrm{~cm})$ was then loaded with $1.5 \mathrm{~mL}$ solution obtained after protamine sulphate treatment and eluted with the same equilibration buffer. Five milliliter $(5 \mathrm{~mL})$ fraction was collected at a flow rate of $0.3 \mathrm{~m} / \mathrm{min}$. Each fraction was assayed for phospholipase $C$ activity and total protein. Subsequently, phospholipase $\mathrm{C}$ active fractions obtained were pooled together, concentrated by dialysis and $5 \mathrm{~mL}$ was applied to a DEAE-Cellulose, DE- 52 column $(2 \times 30 \mathrm{~cm})$. The column was eluted with a linear gradient of $\mathrm{NaCl}(0.025-0.50 \mathrm{M})$ prepared in $0.05 \mathrm{M}$ Tris $\mathrm{HCl}$ buffer. The flow rate was maintained at 0.2 $\mathrm{m} / \mathrm{min}$. Molecular weight of the partially purified enzyme was carried out using SDS- PAGE as described by Laemmli (1970).

\section{Characterization of Partially Purified PLC}

Optimum Temperature of Phospholipase was determined by incubating the mixture of enzyme and substrate at varying temperatures ranging from $30^{\circ} \mathrm{C}-80^{\circ} \mathrm{C}$ for 10 minutes and the activity assayed. The operational stability of PLC was determined by transferring aliquots every hour to ready reaction mixture after incubating the enzyme in a water bath at $60^{\circ} \mathrm{C}$. Residual activity which is directly related to enzyme stability was determined at constant $\mathrm{pH}$, temperature, and ionic strength using the same buffer in all determinations. Half-life of the enzyme was calculated using the formula: $\mathrm{t}_{1 / 2}=0.693 / \mathrm{k}_{\mathrm{D}}$ where $k_{D}$ is the decay constant and is given by $K_{D}=2.303 / t-\log \left(E_{O}, E\right)$, where $\left(E_{O}, E\right)$ is the fraction of enzyme activity remaining after incubation after time t. Activation energy ( $\mathrm{Ea}$ ) was determined by preincubating the enzyme and substrate at $5^{\circ} \mathrm{C}$ interval range from $20^{\circ} \mathrm{C}-80^{\circ} \mathrm{C}$ for 10 minutes before assaying for activity. Arrhenius plot was used to determine $\mathrm{Ea}$. The $\mathrm{pH}$ optimum of phospholipase $\mathrm{C}$ was determined by assaying enzyme activity at varying $\mathrm{pH}$ ranging from $\mathrm{pH}$ 4-9 (acetate buffer for $\mathrm{pH}$ range 4- 5; phosphate buffer for $\mathrm{pH}$ range 6-6.9 and Tris- $\mathrm{HCl}$ buffer for $\mathrm{pH}$ range 7-9). A plot of activity against $\mathrm{pH}$ was used to determine $\mathrm{pH}$ optimum.

\section{Kinetic Studies}

An initial velocity study was done by incubating $100 \mu \mathrm{L}$ enzyme in $100 \mu \mathrm{L}$ each of $0.1,0.2,0.3$, 0.4 and $0.5 \mathrm{mM}$ of the substrate and data obtained was used for double reciprocal plot from which $K_{m}$ and $V_{\max }$ were extrapolated. The effect of $\mathrm{pH}$ on kinetic parameters was estimated from initial velocity of PLC at varying pH of 4, 6, 7.2, 8 and 9 . The $K_{m}$ and $V_{\max }$ were determined at each $\mathrm{pH}$ and Dixon-Webb plot was used to determine the likely ionisable groups in the active site of PLC. Effects of presence and absence of $\mathrm{Ca}^{2+}$, $\mathrm{Zn}^{2+}, \mathrm{Hg}^{2+}, \mathrm{Co}^{2+}$, and $\mathrm{Cu}^{2+}$ on PLC activity was also assayed using a working standard of $10 \mathrm{mM}$ concentration of each ion in the assay medium.

\section{Inhibition Study using aqueous extract of Momordica charantia}

For this purpose, initial velocity study was carried out in the presence and absence of three different concentrations of $M$. charantia (8 $\mathrm{mg} / \mathrm{mL}, 4 \mathrm{mg} / \mathrm{mL}$, and $2 \mathrm{mg} / \mathrm{mL}$ ). LineweaverBurk plot was used to deduce type of inhibition.

\section{Statistical Analysis}

The data were presented as mean \pm standard deviation and Prism® version 3.05 (GraphPad, USA) was used to determine the level of significance at $p<0.05$

\section{RESULTS}

Table 1 presents purification profile of phospholipase $C$ from $O$. capensis venom. It showed a progressive increase in enzyme specific activity from crude sample to the final step of DE-52 anion exchange chromatography. The crude PLC was purified 1.2 folds after undergoing ammonium sulphate precipitation with a percentage yield of $92 \%$. Further purification of the ammonium sulphate treated PLC with protamine sulphate resulted in a 3.6 fold 
purification with a yield of $56 \%$. Subsequent purification on sephadex G-75 column chromatography produced a purification fold of 47.6 with a yield of $11 \%$. Finally, purification on
DE-52 anion exchange chromatography produced a purification fold of 105.2 with a yield of $13 \%$.

Table 1. Summary of Purification Profile of Phospholipase C from the Venom of Opisthacanthus capensis.

\begin{tabular}{llllll}
\hline Fraction & $\begin{array}{l}\text { Total Protein } \\
(\mathrm{mg} / \mathrm{ml})\end{array}$ & $\begin{array}{l}\text { Activity } \\
(\mu \mathrm{mol} / \mathrm{min})\end{array}$ & $\begin{array}{l}\text { Specific Activity } \\
(\mu \mathrm{mol} / \mathrm{min} / \mathrm{mg})\end{array}$ & $\begin{array}{l}\text { Fold } \\
\text { Purification }\end{array}$ & Yield $(\%)$ \\
\hline $\begin{array}{l}\text { Crude Protein } \\
\text { Ammonium Sulfate }\end{array}$ & 0.70581 & $1.492 \times 10^{-2}$ & $2.1134 \times 10^{-2}$ & 1.0 & 100 \\
$\begin{array}{l}\text { Precipitation } \\
(30-60 \%)\end{array}$ & 0.52268 & $1.3725 \times 10^{-2}$ & $2.6259 \times 10^{-2}$ & 1.2 & 92 \\
$\begin{array}{l}\text { Protamine Sulfate } \\
\text { precipitation }\end{array}$ & & & & & \\
Sephadex G-75 & 0.1100 & $3.2679 \times 10^{-3}$ & $2.9700 \times 10^{-2}$ & 3.6 & 56 \\
& 0.00161 & $6.405 \times 10^{-4}$ & $3.9700 \times 10^{-1}$ & 47.6 & 11 \\
DE-52 anion Exchange & 0.00088 & $7.712 \times 10^{-4}$ & $8.7640 \times 10^{-1}$ & 105.2 & 13 \\
\hline
\end{tabular}

Effects of $\mathrm{pH}$ and Temperature on Phospholipase C Activity

Figure 1 shows the effect of $\mathrm{pH}$ on the activity of phospholipase C. A plot of phospholipase C activity against varying $\mathrm{pH}$ revealed that the optimum $\mathrm{pH}$ for the purified phospholipase $\mathrm{C}$ was 7.2. Similarly, Figure 2 shows the effect of temperature on the activity of phospholipase C. A plot of phospholipase $C$ activity against varying temperature revealed that the optimum temperature for the purified phospholipase $\mathrm{C}$ was $60^{\circ} \mathrm{C}$.

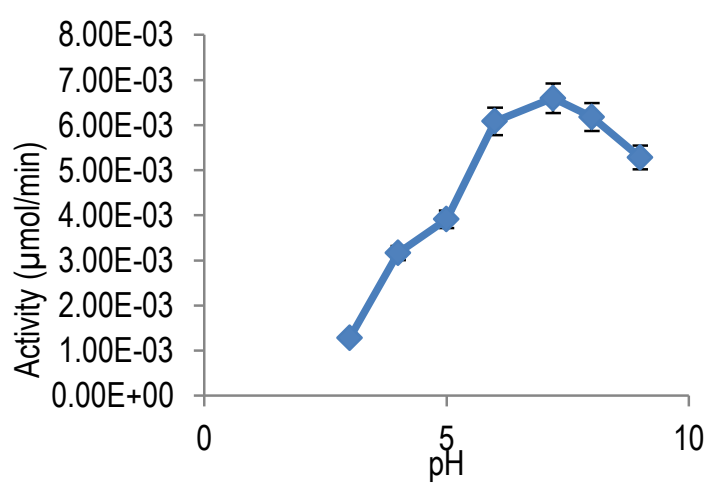

Figure 1: Effects of $\mathrm{pH}$ on Phospholipase C Activity

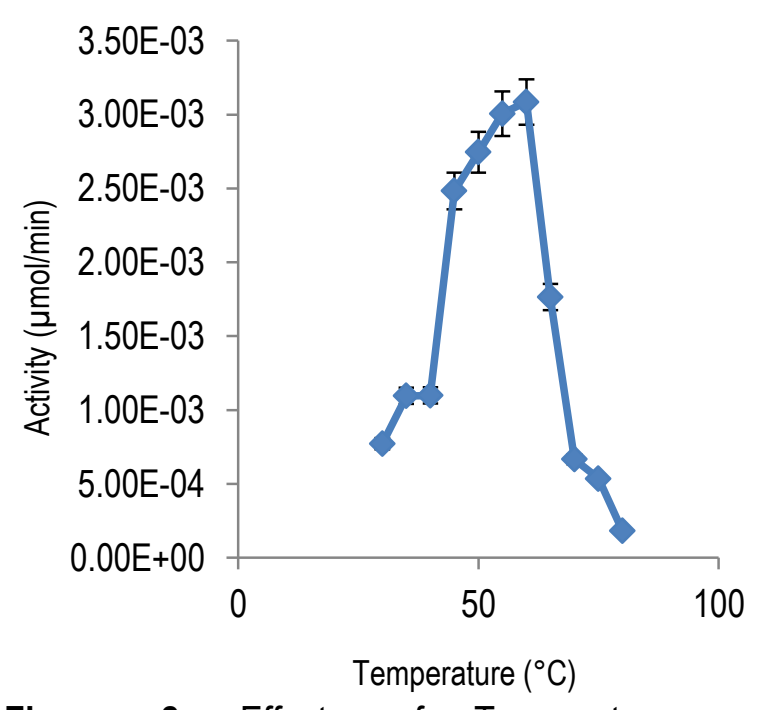

Figure 2: Effects of Temperature on Phospholipase C Activity.

The activation energy deduced from Arrhenius plot (Figure 3) was calculated as $25 \mathrm{~kJ} / \mathrm{mol}$ while the operational stability of Phospholipase $\mathrm{C}$ at $37^{\circ} \mathrm{C}$ after 12 hours incubation was $43 \%$ with a $\mathrm{t}_{1 / 2}$ of 1.50 hours (Figure 4). 


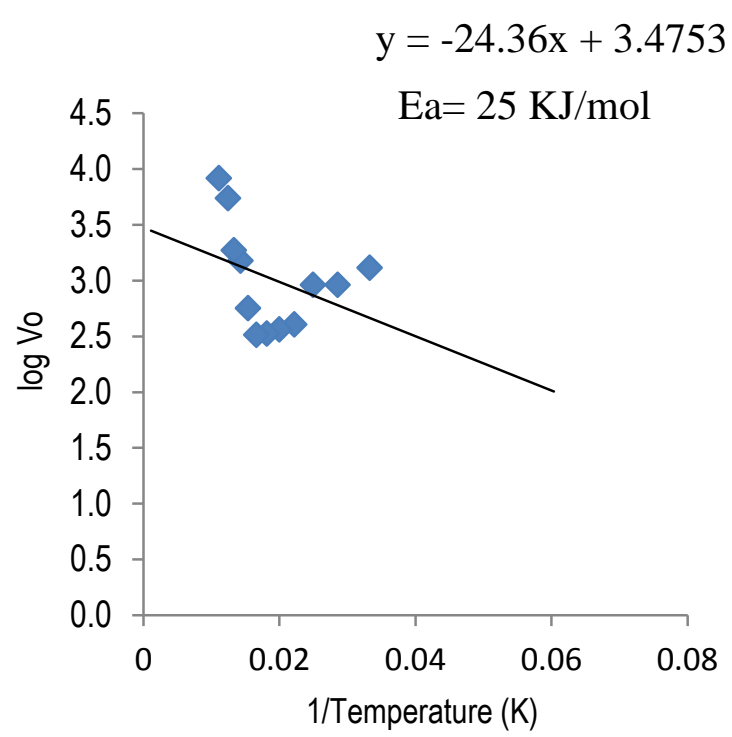

Figure 3: Arrhenius Plot for Phospholipase C

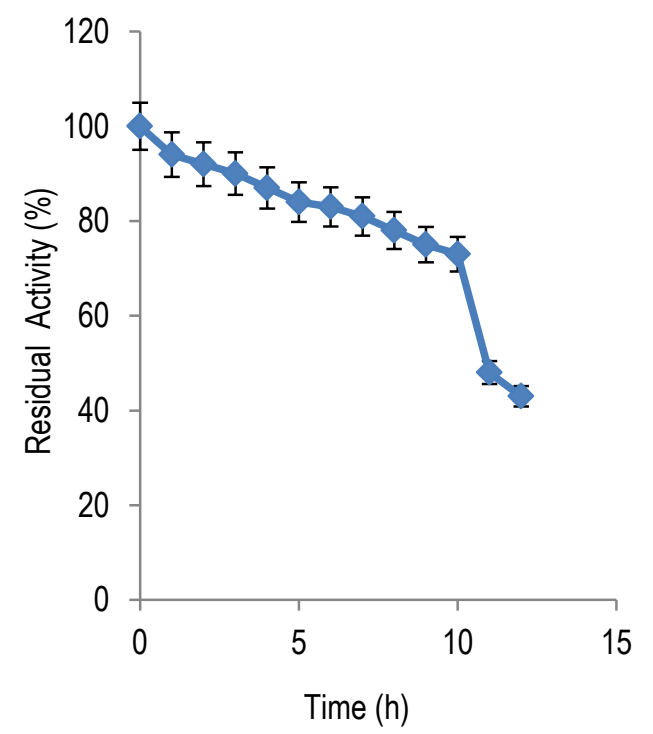

Figure 4: Operational Stability of Phospholipase $\mathrm{C}$ at $37^{\circ} \mathrm{C}$

Double reciprocal and Dixon plot of Partially Purified Phospholipase $\mathrm{C}$ are presented in Figures 5 and 6 respectively. The $K_{m}$ and $V_{\max }$ were $0.02 \mathrm{mM}$ and $0.015(\mu \mathrm{mol} / \mathrm{min})$; while the $\mathrm{pKa}_{1}$ and $\mathrm{pKa}_{2}$ values were approximately estimated to be 6.9 and 7.4 respectively (Figure $6)$.

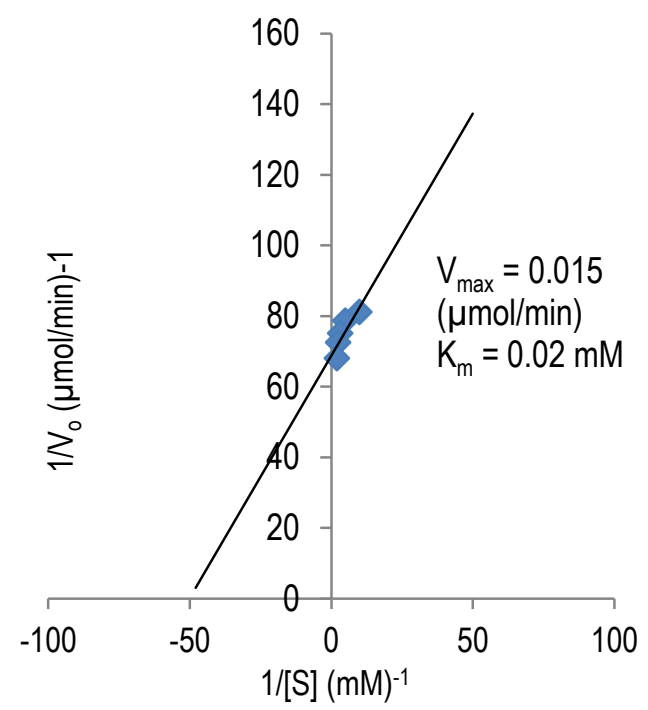

Figure 5: Double Reciprocal (Lineweaver- Burk) Plot of Purified Phospholipase C

Effect of divalent cations on the Activity of Phospholipase $\mathrm{C}$ as presented in Figure $7 \mathrm{a}$ and $7 \mathrm{~b}$ show the effect of different divalent cations on phospholipase C activity. It represents phospholipase $C$ activity in the presence of ions and control.

\section{Inhibition Study on Phospholipase C Activity}

Figure 8 Depicts the Lineweaver-Burk plot of competitive inhibition of phospholipase $C$ by aqueous extract of Momordica charantia. The set of data showing a series of lines crossing the $Y$ $(1 / \mathrm{V})$ axis at the same point that is $V_{\max }$ is unchanged, but with increase in $\mathrm{K}_{\mathrm{m}}$ as the concentration of Momordica charantia was increased.

\section{SDS-PAGE Electrophoregram of Phospholipase C}

Figure 9 shows the SDS-PAGE Banding Pattern of Phospholipase C. Lane 1- marker proteins (from top $150 \mathrm{kDa}, 80 \mathrm{kDa}$, and $25 \mathrm{kDa}$ ), lane 2crude phospholipase $\mathrm{C}$, lane 3-partially purified phospholipase $\mathrm{C}$ after ammonium sulfate fractionation, lane 4-partially purified phospholipase C after protamine sulfate treatment, lane 5-partially purified phospholipase C using Sephadex G-75 column chromatography, 
and lane 6-partially purified phospholipase C using DE-52 anion exchange chromatography.

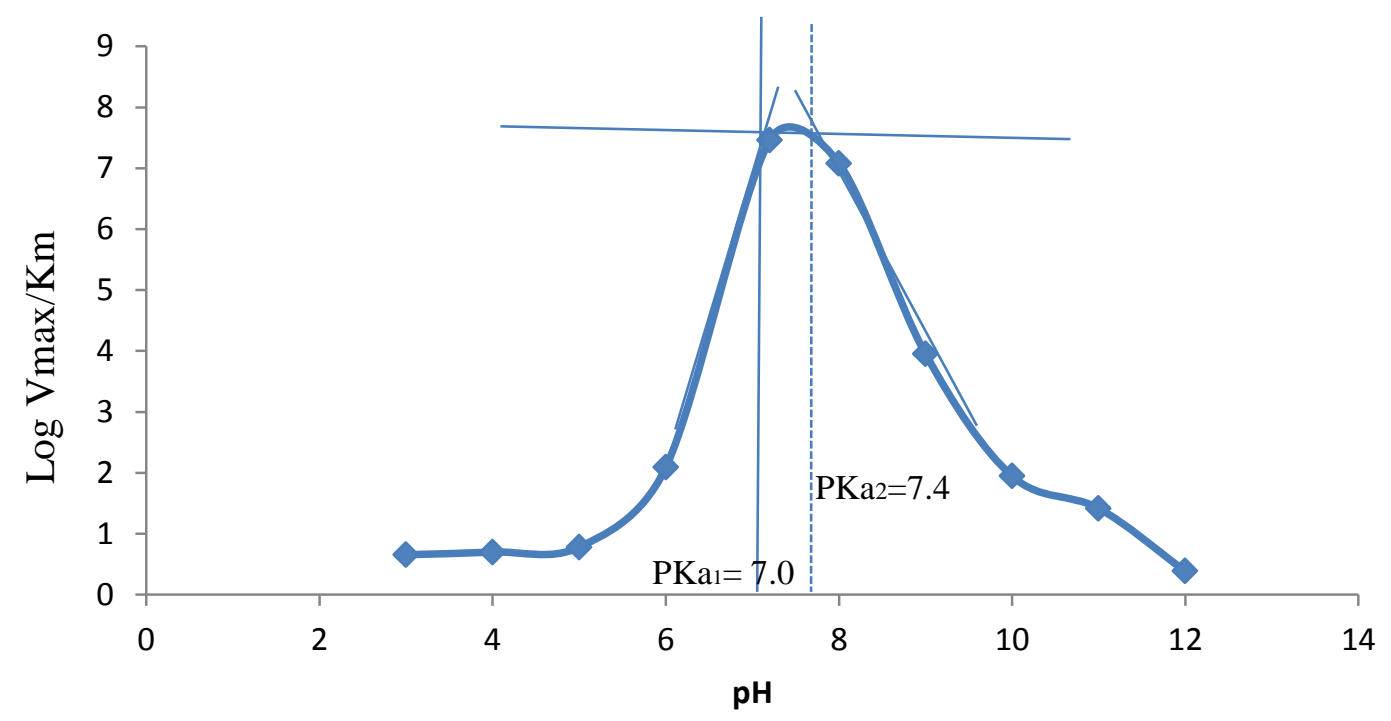

Figure 6: Dixon plot for Opisthacanthus capensis Venom Phospholipase C. pka ${ }_{1}$ and $p K a_{2}$ values are deduced from the $\mathrm{pH}$ values corresponding to the tangent points

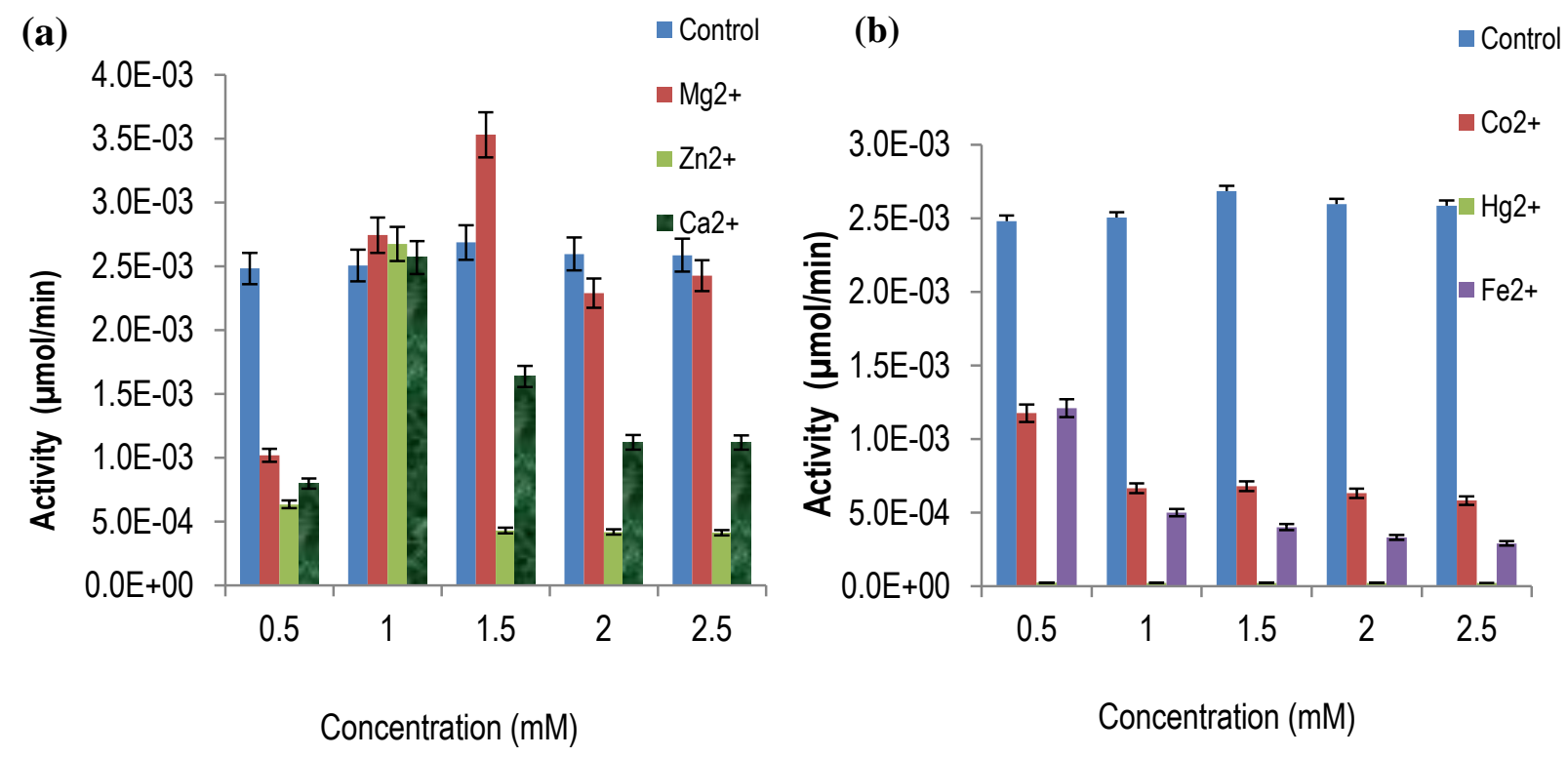

Figure 7: Effect of Divalent Cations on Phospholipase C Activity. (a) effect of $\mathrm{Mg}^{2+}, \mathrm{Zn}^{2+}$, and $\mathrm{Ca}^{2+}$ on phospholipase $\mathrm{C}$ activity and (b) effect of $\mathrm{Co}^{2+}, \mathrm{Hg}^{2+}$, and $\mathrm{Fe}^{2+}$ on phospholipase $\mathrm{C}$ activity. 


\section{Nigerian Journal of Basic and Applied Science (June, 2017), 25(1): 01-10}

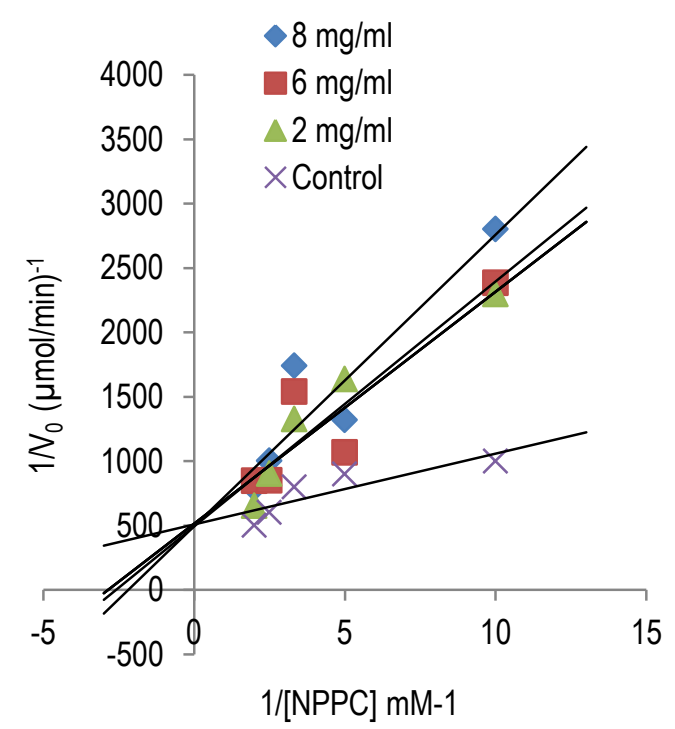

Figure 8: Lineweaver-Burk plot showing Competitive Inhibition of Phospholipase $C$ by Aqueous Extract of Momordica charantia.

$$
\begin{array}{llllll}
1 & 2 & 3 & 4 & 5 & 6
\end{array}
$$

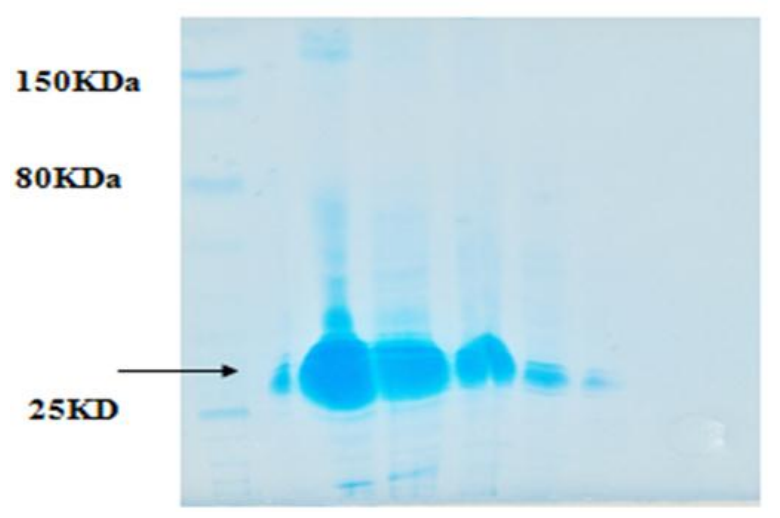

Figure 9: SDS-PAGE Electrophoregram of phospholipase $\mathrm{C}$.

Lane $1=$ molecular weight marker; lane $2=$ ammonium sulphate fraction; lane $3=$ protamine sulphate fraction;lane 4 = sephadex $\mathrm{G} 75$ fraction; lane $5=\mathrm{DE}-52$ anion exchange fraction

\section{DISCUSSION}

The purification steps of phospholipase $C$ from 0 . capensis venom indicated both the crude and purified samples exhibited phospholipase $C$ activity. The purified enzyme also exhibited appreciable degree of operational stability at $37^{\circ} \mathrm{C}$ which might be one of the factors that the microbial source of the enzyme is used for the enzymatic degumming of phospholipids in addition to its thermal stability (Dayton et al., 2010).

Scorpion venom contains small and larger molecular weight components (Rodolfo et al., 2013). In this study, $O$. capensis venom phospholipase $C$ was purified 105.2 fold with overall yield of $13 \%$ and a specific activity of $8.784 \times 10^{-1} \mu \mathrm{mol} / \mathrm{min} / \mathrm{mg}$. Hirata et al., (1995) reported that phospholipase $\mathrm{C}$ (in the supernatant of Clostridium perfringens homogenate) was recovered at $60 \%$ ammonium sulphate saturation, supporting the present study.

The estimated molecular weight of $29 \mathrm{KDa}$ from SDS polyacrylamide gel electrophoresis was similar to the molecular weight of phospholipase C, $29 \mathrm{KDa}$ and 24 $\mathrm{KDa}$ from Listeria monocystogens (Geoffroy et al., 1990) and L. ivanovii (Jürgen et al., 1984) respectively. The same enzyme from Clostridium perfringens gave a molecular weight of $43 \mathrm{KDa}$ (Hale and Stiles, 1999). However, phospholipase $C$ isolated from cells of haematopoietic origin in humans gave a molecular weight of $133.7 \mathrm{KDa}$ (Bertognolo et al., 2007).

The optimum pH of 7.2 indicated that the enzyme could operate optimally at physiological $\mathrm{pH}$. This report is in agreement with a previous report by Kurioka and Liu, (1967). Patricia et al (2009) reported a pH optimum of 7.0 for phospholipase $C$ from $C$. perfringens.

The enzyme was found to be active at a wide range of temperatures from $30^{\circ} \mathrm{C}$ to $75^{\circ} \mathrm{C}$ with an optimum at $60^{\circ} \mathrm{C}$ (Fig. 2.), but lost its activity at $80^{\circ} \mathrm{C}$ probably due to denaturing at elevated temperature (Mandels and Andreotii, 1976). A previous study found that the optimum temperature of phospholipase $C$ from Bacillus mycoides was $60^{\circ} \mathrm{C}$ (Chang et al., 2010). The activation energy of phospholipase $C$ using $p$ nitrophenyl phosphorylcholine as a substrate was found to be $25.00 \mathrm{KJ} / \mathrm{mol}$ (Figure 3). Enzymes usually operate by effectively lowering the amount of energy required to start a reaction. Sometimes this happens because enzymes might weaken a covalent bond within a substrate molecule (Temple, 2012). In other 
cases this lowering of activation energy seems to happen because the enzyme holds the substrate molecule in a particular orientation that increases the likelihood hood that the molecules are going to react (Temple, 2012). Without the enzyme much more activation energy is required to get the reaction to take place (Temple, 2012).

The $K_{M}$ of $0.02 \mathrm{mM}$ indicates high substrate affinity. The stability at $60^{\circ} \mathrm{C}$ makes phospholipase $\mathrm{C} \mathrm{a}$ potentially suitable biocatalyst for industrial processes especially for degumming of phospholipids in the food industries. The differences in organism/species might contribute to the differences in $\mathrm{K}_{\mathrm{m}}$ and $\mathrm{V}_{\max }$ found in other organisms/species (Hafiz et al., 2011).

The partially purified phospholipase $C$ was found to be positively modulated by $\mathrm{Mg}^{2+}$ ion at concentration of $1.5 \mathrm{mM}$, but at higher concentration, it inhibited the enzyme activity. The metal may reside at sites other than the active site and change the conformation of phospholipase $\mathrm{C}$ or it may bind near the active site and effect some conformational changes. In this way, $\mathrm{Mg}^{2+}$ ion may facilitate binding of the substrate $p$ nitrophenyl phosphorylcholine to the enzyme. However, $\mathrm{Ca}^{2+}$ and $\mathrm{Zn}^{2+}$ slightly show positive modulatory effect on the enzyme, but $\mathrm{Co}^{2+}$ and $\mathrm{Fe}^{2+}$ inhibited phospholipase $\mathrm{C}$. The catalytic activity of phospholipase $\mathrm{C}$ depends on $\mathrm{Ca}^{2+}$ as a cofactor and the activity increases with a rise of $\mathrm{Ca}^{2+}$ concentration within the physiological range $(0.01-10 \mu \mathrm{m})$ (Mara et al, 1998). Certain bacteria phospholipase $C$ requires $\mathrm{Mg}^{2+}$ for maximum catalysis (Richard, 1993). $\mathrm{Hg}^{2+}$, completely inhibited phospholipase $\mathrm{C}$. These ions may have also occupied the same site on phospholipase $\mathrm{C}$ as $\mathrm{Mg}^{2+}$ but induce a conformational change such that substrate no longer fits into the active site. Since $\mathrm{Hg}^{2+}$ has strong affinity for sulfhydryl $-\mathrm{SH}$, it can irreversibly bind to the $(\sim \mathrm{SH})$ group of phospholipase $\mathrm{C}$ and completely inhibits its activity (Angelovicovâ et al., 2014). The decreasing order of effectiveness of these divalent cations is as follows; $\mathrm{Mg}^{2+}>>\mathrm{Ca}^{2+}>\mathrm{Zn}^{2+}>\mathrm{CO}^{2+}>\mathrm{Fe}^{2+}>\mathrm{Hg}^{2+}$. This shows that phospholipase $\mathrm{C}$ is a metalo enzyme (Kurioka and Matsuda, 1976).

It is evident that the phospholipase C from Opisthacanthus capensis venom was competitively inhibited by the aqueous extract of Momordica charantia with an inhibition constant (Ki) of $4.2 \mathrm{mM}$ (Figure 8). This indicates that the constituents of the aqueous extract of Momordica charantia binds reversibly to the active site of the enzyme and occupies it in a mutually exclusive manner with the substrate forming enzyme - inhibitor complex. This can be reversed by increasing the concentration of $p$ nitrophenyl phosphorylcholine. The values of $V_{\max }$ were found to be significantly not altered, while the $\mathrm{K}_{\mathrm{M}}$ values were significantly altered. This is because $V_{\max }$ is a function of all enzyme molecules uniting with the substrate (Johnson et al., 2010). The Michaelis constant $\mathrm{K}_{\mathrm{M}}$, on the other hand, will be altered with changes in the concentration of Momordica charantia because it requires larger concentration of the substrate, $\quad p$ nitrophenyl phosphorylcholine to overcome the direct competition by Momordica charantia for the active site.

The study on the ionisable groups in the active site of phospholipase $C$ revealed the presence of groups with enthalpy of ionization of $20 \mathrm{KJ} / \mathrm{mol}$. This result is suggestive of histidine in or around the active site of the enzyme. Ionisable groups at the active site of plant phospholipase $C$ have been shown include histidine residue (Amerjeet et al., 2015). This residue is well conserved in eukaryotic phospholipase $C$ (Amerjeet et al., 2015). Therefore, substrate recognition and mechanism of catalysis are likely to be similar in all eukaryotic phospholipase C (Marchler-Bauer et al., 2015).

\section{CONCLUSION}

From the characteristics of the enzyme observed, Opisthacanthus capensis can serve as a potential source of phospholipase $\mathrm{C}$ and the use of Momordica charantia extract by local population especially in North Eastern part of Nigeria as anti-scorpion venom have some scientific basis. Therefore, the active ingredients in Momordica charantia responsible for the in vitro inhibition of phospholipase $\mathrm{C}$ should be isolated and studied. Also, the gene for phospholipase C from Opisthacanthus capensis should be isolated, cloned and expressed. 


\section{Nigerian Journal of Basic and Applied Science (June, 2017), 25(1): 01-10}

\section{ACKNOWLEDGEMENTS}

We wish to extend our gratitude to Prof. Abubakar Gidado and Dr. M. A. Milala of the Department of Biochemistry, University of Maiduguri for their tremendous support towards the completion of this work.

\section{REFERENCES}

Allan, D, and Michell, R. H. (1974). Phosphatidylinositol cleavage catalysed by the soluble fraction from lymphocytes. Activity at $\mathrm{pH} 5.5$ and $\mathrm{pH} 7.0$. Biochemistry Journal, 142(3): 591-597.

Amerjeet, S., Nikita, B., Amita, P. and Girdhar, K.P. (2015). Plant phospholipase C family:regulation and functional role in lipids. Cell calcium, 58: 139-46.

Angelovicovâ, L., Loderius, M. and Tulisalo, F. and Fazekasôvâ, D. (2014). Effect of heavy metals on soil enzyme activity at different field conditions in Middle Spis mining area (Slovakia). Bulletin of Environmental Contamination and Toxicology. 93 (6): 670-5.

Bertognolo, V., Brugnoli, F., Benedus, M. and Capitani S. (2007). PLCB2 (phospholipase C, bête 2). Alas of Genetics and Cytogenetic in Oncology and Haematology. 11 (4): 308- 310.

Chang, G. W., Ming, K.C. and Tao, C. (2010). Improved purification and some properties of a novel phospholipase $\mathrm{C}$ from Bacillus mycoides strain 970. African Journal of Microbiology Research. 4 (5), pp. 396-399.

Chu, H.P. (1949). The lecithinase of $B$. cereus and its comparism with C. welchii alpha toxin. Journal of General Microbiology 3: 255-273.

Dayton, C.L.G., Staller, K., and Berkshire, T.L. (2010). Process of improving enzymatic degumming of vegetable oils and reducing fauling of downsream process equipment. US Paten, 7: 713-727.

Emam, S.J., Khosravi, A.D. and Alemohammad, A. (2008). Evaluation of hemtological and urine parameters in Hemiscorpius lepturus (Gadim) victims referred to Razi hospital, Ahwaz, Iran. Journal of Medicinal Sciences, 8:306-309.

Geeffroy, C., Ravercau, J., Alouf, J.E., and Berche, P. (1990). Purification and characterization of phospholipase $\mathrm{C}$ from listeria monocystogens and listeria ivanovii zentralbi. Bacteriol. Parasitenkd. Infektionskr. Hyg.Abt. I orig. Reche A. 519: 425- 426.

Hafiz, M.N.I., Ishtiaq, A., Muhammad, A.Z. and Muhammad, I. (2011). Purification and characterization of the cellulose produced from wheat straw by Trichoderma viride under SSF and its detergent compatibility. Advances in Bioscience and Biotechnology 2: 149156.

Hale, M.L., and Stiles, B.G. (1999). Detection of Clostridium perfringens alpha toxins using a capture antibody ELISA. Toxicon. 37: 491- 484.

Hirata, Y., Minami, J., Koyama, M., Matsushita, O., Katayama, S.I., Jin, F., Maeta, H., and Okebe, A.A. (1995). "Method for purification of Clostridium perfringens phospholipase C from recombinant Bacillus subtilis cells. Journal of Applied and Environmental Microbiology 61, $\mathrm{p}$ 4114-4115.

Johnson, D.S., Weerapana, E., and Cravatt, B.F. (2010). Strategies for discanning and derisking covalent, irreversible enzyme inhibitors. Future Medicinal Chemistry. 2(6): 949-64.

Jürgen, K., Dorothe, F., Albert, H., Friedrich, L. and Werner G. (1984). Production, purification and characterization of Listeria ivanovii and Listeria monocystogens Sv4b. Microbiology letters 37, 197- 202.

Kumar, S., Seth, S., and Jaiswal, A. (2009). Chronic beta- adrenergic activation induced left ventricular systolic dysfunction is associated with systemic release of TNF- alpha and IL- beta in 
rats. Pharmacological Report, 61: 870876.

Kurioka, S. and Liu, P,V. (1967). Improved Assay Method for Phospholipase C. Applied Microbology, 15(3): 551-555.

Kurioka, S., and Matsuda, M. (1976). Phospholipase C assay using $p$ Nitrophenyl phosphorylcholine together with Sorbitol and its application to studying the metal and detergent requirement of the enzyme. Analytical Biochemistry, 75: 281-289.

Laemmli, U.K. (1970). Cleavage of structural protein during the assembly of head of bateriophage T4. Nature. 227(5259): 680-685.

Mandels, M., and Andreotii, R.C. (1976). Measurement of saccharifying cellulose. Biotechnology and Bioengineering Symposium 6:2-23.

Mara, V.E., Stephen, R.J., Olga, P., Dawnes C.P., Rogers, I. W. and Matilda K. (1998). Catalytic domain of phosphoinositides- specific phospholipase C. The Journal of Biological Chemistry. 2731 (19): 1165011659

Marchler- Bauer, A., Derbyshire, M.K., Gonzales, N.R., Lu, S., Chitsaz, F., Geer, L.Y. Geer, R.C., He, J., Gwadz, M., Harwitz, D.I., Canczyck, C.J., Lu,F., Marchler, C.H., Song, J.S., Thanki, N., Wang, Z., Yamashita, R.A., Zhang, C., and Bryont, S.H. (2015). CDD: NCBl's conserved domain database. Nucleic Acids Research 43 (Database issue): D222- 6 .

Nooran, E., Walid, F.E., Muhammad, M.A., and Nadia, A.H. (2016). Production and characterization of phospholipase $C$ from some Bacillus thuringiensis isolates recovered from Egyptian soil. Industrial Journal of Biotechnology for Wellness Industries, volume 5:10-24.

Petricevich, V.L. (2010). Scorpion venom and the inflammatory response. Mediators Inflammation 2010: 903295. Patricia, U.,
Marietta, F. D, Alberto, A.G., Alicia, A. and Felix, M,G, (2009). Phospholipase and Shingomyelinase activities of the Clostridium perfringens a-toxins. Chemistry and Physics of Lipids 159:5157.

Richard, W.T. (1993). Bacterial phospholipase C". American Society for Microbiology. Microbiology Reviews, (4): 347- 366.

Rodolfo, R.R., Fredy, I.V.C., Fernando, Z.Z., Lidia, G.M., Georgia, E.L., Ariel, R.U. and Lourival, D.P. (2013). The Cuban scorpion Rhopulurus junceus (Scorpiones, Buthidae): component variation in venom samples collected in different geographical areas. Journal of Venomous Animals and Toxins. 19:1315.

Slein, M.W. and Logan G,E, (1963). "Partial purification and properties of two phospholipases of Bacillus cereus". Journal of Bacteriology 85:369-381.

Stoscheck C.M. (1990). Quantitation of protein. Methods in Enzymology 182: 50-69.

Urbina, P., Flores-Diaz, M., and Alape, G. (2011). Effects of bilayer composition and physical properties on the phospholipase $C$ and Sphingomyelinase activities of $C$. Perfringens alpha- toxin. Biochimica Et Biophysica Acta Biomembranes, 1808 (1):279-286.

Temple, V.J. (2012). Biochemistry 1001: Review and Viva voce Questions and Answers Approach. Sterling publishers Private Limited, New Delhi-110-020. 